\section{THE APPLICATION OF GLOBAL GRAMMAR THEORY TO LOCATIVE AND DIRECTIONAL STRUCTURES IN CHINESE, THAI AND ENGLISH}

\section{Chanyaporn Parinyavottichai ${ }^{1}$}

\begin{abstract}
This paper employs the Global Grammar theory to analyze locative and directional phrases in Mandarin, Thai and English. I use translation-equivalent sentences from Mandarin, English, and Thai to illustrate the relation between the global grammar and its derived regional grammars and to show how the translation-equivalent sentences can become partly similar and partly dissimilar to each other. This paper also shows how a language teacher of Mandarin Chinese can effectively use the relation between the Global grammar and particular grammars to help students whose native language is English and Thai to learn the syntax and semantics of any Chinese sentence.
\end{abstract}

\section{Introduction}

The Global Grammar theory (Hsieh 2004, 2005) emerged from Compositional Cognitive Grammar (Hsieh 1992, 1994, 2000), a theoretical framework that balances two competing theories, linguistic universalism and relativism. As Hayden (1997) explains, Compositional Cognitive Grammar offers a means for

\footnotetext{
${ }^{1}$ Lecturer, Department of Eastern Languages, Faculty of Arts, Chulalongkorn University, Bangkok
}

systematic comparisons of syntactic and semantic features of various languages. According to Hayden, human languages are similar in that they share universal constraints at the compositional or the Image-Structure (IR) level (for details, see Hsieh 2000:68). On the other hand, languages are dissimilar in that similar images may be perceived differently by speakers of different languages and thus expressed in different ways. Since the Compositional Cognitive Grammar theory is beyond the scope of this study, I will not discuss it in detail here. This paper focuses on the principles of the Global Grammar theory and its pedagogical implications. To illustrate the principles of Global Grammar, I have chosen locative and directional expressions in Chinese, Thai, and English. The reason for these choices is that locative and directional structures are easy to construe by second language (L2) learners.

In the first section of this paper, I will present a discussion of the principles of Global Grammar. The second section describes the temporal sequences and two processes of language expression (i.e., compression and decomposition), which help to illustrate how Global Grammar operates. The third section offers an analysis of the two unique directional complements in Thai and Chinese come and go. The fourth section discusses the pedagogical implications of Global Grammar. This paper concludes that Global Grammar is applicable in second language teaching and learning.

\section{Principles of global grammar}

In a sense, Global Grammar is the grammar of a global language. It focuses on how regional divergence can be described by a postulated global grammar. 
Generally speaking, Global Grammar contains a maximal set of expressions obtained from its regional languages. Further, the similarities among the various regional grammars, rather than the differences, are emphasized in this theory. Thus, Global Grammar is helpful for comparing cross-linguistic differences, which may assist language learners in analyzing semantically similar expressions among languages. To understand the key concepts in Global Grammar, let us see Table 1.

Table 1: Illustration of Global Grammar by comparing it to the clothing preferences of three girls of different nationalities ${ }^{2}$

\begin{tabular}{|l|l|l|l|l|l|l|}
\hline \hline Nationality & Shoes & Top & Pants & Dress & Gloves & Hair-band \\
\hline Thai & $\phi$ & 0 & & $\phi$ & & $\varnothing$ \\
\hline Chinese & & & & & \\
\hline
\end{tabular}

\footnotetext{
${ }^{2}$ The pictures of these three girls were taken from the following websites, www.istockphoto.com imageindex/173/0/173026/, www.chinese2learn.com/images/cartoon/girl_03.jpg, and www. hasslefreeclipart.com.
} 
Based on Table 1, there are three girls: Thai, Chinese and American girls. Thai girl wears top, pants and gloves. Chinese girl wears shoes, top and pants. American girl wears shoes, dress and hair-band. We can see that each girl has different preferences in what she wants to wear. In terms of Global Grammar, they are dissimilar in selecting the foreground and background features. A foreground is a prominent feature that cannot be omitted, while a background feature refers to an insignificant feature that can be ignored. The background feature here is signified by the symbol of an empty set, $\varnothing$. In the 'Top' column, for example, there are two different tokens, which can be grouped into one type, 'Top.' In relation to the key concepts in Global Grammar, the pictures in this table can show the relationship of the following categories:

Maximum pieces of clothing $=\{$ shoes, tops, pants, dress, gloves, hair-band $\}$

Regional dress $=\{$ Thai clothing $\} /\{$ Chinese clothing $\} /\{$ American clothing $\}$

Global dress $=$ Three sets of regional dress, they are $\{$ Thai clothing $\}+\{$ Chinese clothing $\}+\{$ American clothing $\}$

The above categories can be compared to three key concepts in the Global Grammar theory:

Maximum pieces of clothing $=$ Global features

Regional dress $=$ Regional expression

Global dress $\quad=$ Global expression

Now, let us consider the following set of translation-equivalent sentences:

a. John walked out of the room.

(English)

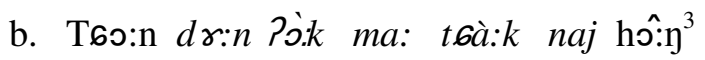

John walk out come from in room

'John walked out of the room.'

c. T60:n $d r: n$ Pò:k t6à:k hô:y

John walk out from room

'John walked out of the room.'

d. Yuēhàn ${ }^{4}$ cóng fángjiān lì zǒu le chūlai. ${ }^{5}$ (Chinese)

John from room in walk Perf. ${ }^{6}$ out+come

'John walked out of the room.'

\footnotetext{
${ }^{3}$ The Romanization system for Thai is from the International Phonetic Alphabet (IPA)

${ }^{4}$ The Hanyu Pinyin Romanization system is used for Mandarin Chinese in this paper.

${ }^{5}$ lái and qù have a neutral tone when they are attached to action verbs shàng 'ascend', xià 'descend',

jìn 'enter', chī 'exit, go/come out', huí 'return', guò 'cross', and qü 'rise'.

${ }^{6}$ Perf. stands for perfective aspect.
} 
As Example (1) shows, although these three languages convey the same idea of John walking out of the room, they select different numbers of actions. The event of John's walking out of the room can be understood easily by resorting to the full image of a series of decomposed ${ }^{7}$ actions: John was in the room, departed from the room, and walked out of the room towards the speaker. From the three regional languages, we can identify six possible global features $\{$ in, from, walk, out, come, of \}, from which English selects only three features \{walk, out, of $\}$ to form its regional expression. Thai, however, can express this event in two ways, either more decomposed \{walk, out, come, from, in\}, or more compressed \{walk, out, from \}. Similar to the decomposed way of expression in Thai, Chinese also selects five features \{from, in, walk, out, come to form its regional expression. The sum of the three regional expressions form the global expression (\{walk, out, of $\}+\{$ walk, out, come, from, in $\}+\{$ from, in, walk, out, come $\})$. Certain foreground features occur only in particular regional languages.

\footnotetext{
${ }^{7}$ I will define the terms "decomposition" and "compression" more thoroughly in the next section.
}

\section{Temporal sequences and two processes of language expression}

Regional languages may focus on different portions of the temporal sequences of an event. For example, some languages may choose to express merely the initial or starting action of the event, while others may denote either its final action or the action in between the initial and final actions. Let us consider Example (2). 

a. Mary takes a plane to Beijing. (English)
b. Me:rí nây k $\mathrm{k}^{\mathrm{h}} \mathrm{rw} a \mathrm{a} y b i n$ paj Pàkkìn (Thai)
Mary sit airplane go Beijing
'Mary takes a plane to Beijing.'
c. Me:rí $k^{h} u \hat{n} \quad \mathrm{k}^{\mathrm{h}}$ ru:âybin paj Pàkkìn
Mary get on airplane go Beijing
'Mary takes a plane to Beijing.'
d. Mălì zuò fêijī qù Běijīng.
Mary sit airplane go Beijing
'Mary takes a plane to Beijing.'
e. Mălì zuò fēijī dào Běijīng qù. (Chinese)
Mary sit airplane to Beijing go
'Mary takes a plane to Beijing.'

In the temporal sequence of an event such as moving from one place to another, departing from the starting point precedes the stage of arriving at the destination. Thus, in the complex event 'Mary takes a plane to Beijing', the action 'to Beijing follows the action takes a plane'. We can also delve deeper into this example by employing the two opposite processes of expression: compression and decomposition. Compression refers to the process of reducing information, mostly redundant data, without losing the essential information of an event. Decomposition, on the other hand, is a process of breaking down an event into smaller component units. For example, we can sub-divide or decompose the event 'Mary takes a plane to Beijing' into several sub-events: Mary gets on/takes the airplane, she sits on the airplane, and finally the airplane reaches its destination 'Beijing'. In English, the initial point of the complete event is focused on, but Thai and Chinese merely describe the inbetween action by using the action verb ${ }^{8}$

${ }^{8}$ Action verb here refers to a genuine verb and preposition indicating motion. nây/zuò 'sit'. However, Thai can also describe this event in the same way as in English. That is, it can emphasize the initial action $k^{h} u \hat{n}$ 'get on'.

Chang (1998) notes that a verb like fetch in English can have a long sequence of decomposed actions in Chinese, qù ná (guò)lai, go-take-(cross)-come, 'to go and bring it (all the way) back'. Wang (1998) also points out that a short sequence of words in English such as 'the painting fell off the wall' can be expressed by a long sequence of words in Chinese: Huà cóng qiáng shàng diào xiàlai. 'painting-fromwall-upper part-fall-descend+come.' Wang observes that such a contrast between English and Chinese affects the selection of features in the foreground or background.

The process of decomposition may assist second or foreign language learners in understanding or constructing regional expressions. Different languages require different features to be selected for the foreground or background. Some features must be foregrounded in some languages. However, the same features may be 
backgrounded in other languages. In other words, some information that must be mentioned in one language may be omitted in another. Consider the following set of sentences:
a. Peter jumped
out of
the bed
(English)

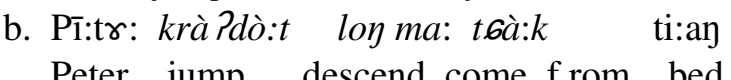
'Peter jumped out of the bed.'
c. Bǐdé tiào xià chuáng lái.
Peter jump descend bed come
'Peter jumped out of the bed.'
(Chinese)
Peter from bed on jump Perf. descend+come
'Peter jumped out of the bed.'
d. Bǐdé cóng chuáng shang tiào le xiàlai. (Chinese)

These four sentences above demonstrate how English, Thai, and Chinese describe the action 'Peter jumped out of the bed' in the different regional expressions. In English, three actions are foregrounded: 'jump, out and of'. Thai foregrounds four actions: krà Pdò:t 'jump,' loy 'descend', $m a$ : 'come', and t6à: $k$ 'from'. Chinese can foreground either three actions tiào 'jump,' xià 'descend,' and lái 'come' as in (c), or four actions cong 'from', tiào 'jump,' xià 'descend,' and lái 'come' as in (d). Hsieh (2006) explains the differences between (c) and (d) by noting that tiào 'jump' is prominent in Chinese and is used as a verb, but cóng 'from' is less prominent and is used as a co-verb. Hsieh substantiates his view by discussing the derivational process of the co-verb cóng 'from'. He cites a theory of co-verb development proposed by $\mathrm{Li}$ (1980, as cited in Hsieh 2006: 11), which states that the co-verb cóng 'from' is derived from a full verb. According to Hsieh (2006), cóng 'from,' which is less prominent, can be omitted, leaving fewer actions expressed in (c). The decomposition of this event can be demonstrated in Figure 1 and Table 2 below:



Figure 1: Fully decomposed actions of the event described in sentences (3a - 3d) 
Table 2: Comparison of foregrounded features of the sentence 'Peter jumped out of the bed' in English(ENG), Thai(TH) and Chinese(CHN)

\begin{tabular}{|l|c|c|c|c|}
\hline Action verb & ENG (a) & TH (b) & CHN (c) & CHN (d) \\
\hline from & $\varnothing$ & t6à:k & $\varnothing$ & cóng \\
jump & jump & krà?dò:t & tiào & tiào \\
out & out & $\emptyset$ & $\emptyset$ & $\emptyset$ \\
of & of & $\varnothing$ & $\emptyset$ & $\emptyset$ \\
descend & $\varnothing$ & loy & xià & xià \\
come & $\varnothing$ & ma: & lai & lai \\
\hline
\end{tabular}

Notice that a sequence of six actions occurs in the event 'Peter jumped out of the bed.' However, each language selects different features in its regional expression. English speakers express the event with fewer features foregrounded whereas Thai and Chinese foreground more features in their translation-equivalent sentences. Consider another set of examples:

(4) a. The train came through the tunnel.

(English)

b. Rótfaj lo:t $p^{h} \grave{a}: n$ Pò:k ma: t6à:k naj Pùmo:n (Thai) Train through pass out come from in tunnel 'The train came through the tunnel.'

c. Rótfaj lôt Pò:k ma: toà:k naj Pùmo:n Train through out come from in tunnel 'The train came through the tunnel.'

d. Rótfaj lo:t Pò:k ma: t6à:k Pùmo:y Train through out come from tunnel 'The train came through the tunnel.'

e. Rótfaj Pò:k ma: t6à:k naj Pùmo:n Train out come from in tunnel 'The train came through the tunnel.'

f. Rótfaj Pò:k ma: tøà:k Pùmo:n Train out come from tunnel 'The train came through the tunnel.' 
g. Rótfaj lo:d $p^{h} \grave{a}: n$ Pùmo:y $m a:$

(Thai)

Train through pass tunnel come

'The train came through the tunnel.'

h. Huǒchē cóng suìdào lì chuān guòlai. (Chinese)

Train from tunnel in pass through come

'The train came through the tunnel.'

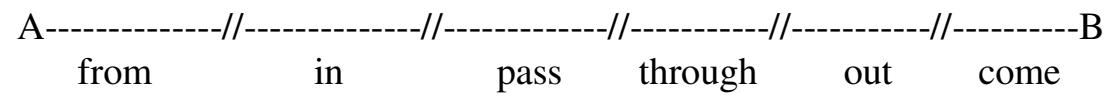

Figure 2: Fully decomposed actions of the event described in sentences $(4 a-4 h)$

Table 3: Comparison of foregrounded features of the sentence 'The train came through the tunnel' in English, Thai and Chinese

\begin{tabular}{|l|c|c|c|c|c|c|c|c|}
\hline $\begin{array}{l}\text { Action } \\
\text { verbs }\end{array}$ & ENG(a) & TH(b) & TH(c) & TH(d) & TH(e) & TH(f) & TH(g) & CHN(h) \\
\hline from & $\varnothing$ & t6à:k & t6à:k & t6à:k & t6à:k & t6à:k & $\varnothing$ & cóng \\
in & $\varnothing$ & naj & naj & $\varnothing$ & naj & $\varnothing$ & $\varnothing$ & li \\
pass & $\varnothing$ & phà:n & $\varnothing$ & $\varnothing$ & $\varnothing$ & $\varnothing$ & phà:n & chuān \\
through & through & lô:t & lôt & lô:t & $\varnothing$ & $\varnothing$ & lôt & guò \\
out & $\varnothing$ & Pò:k & Pò:k & Pò:k & Pò:k & Pò:k & $\varnothing$ & $\varnothing$ \\
come & come & ma: & ma: & ma: & ma: & ma: & ma: & lai \\
\hline \hline
\end{tabular}

In this set of sentences, the global features denote six actions. We can see that the three languages differ in foregrounding the features in their regional expressions. In English, the action verbs come and through are foregrounded, but Thai and Chinese can foreground not only come and through but also pass, although this usage seems to be redundant due to the fact that through and pass describe quite similar actions. In Thai, the compression process can reduce the actions from six to three. The decomposition of this event in the three different languages is illustrated in Figure 2 and Table 3 above. 
Consider one more example:

(5)

a. John hurried back to the hospital from his office. (English)

b. T60:n rî:p klàp t6à:k $t^{h} \hat{\imath}: \mathrm{t}^{\mathrm{h}}$ ampan ma: $\mathrm{t}^{\mathrm{h}} \hat{\imath}:$ ro:ypaja:ba:n (Thai) John hurry back from at office come at hospital 'John hurried back to the hospital from his office.'

c. Yuēhàn cóng bàngōngshì găn huílai dào yīyuàn. (Chinese) John from office hurry return+come to hospital

'John hurried back to the hospital from his office.'

d. Yuēhàn cóng bàngōngshì găn huí dào yīyuàn. (Chinese)

John from office hurry back to hospital

'John hurried back to the hospital from his office.'

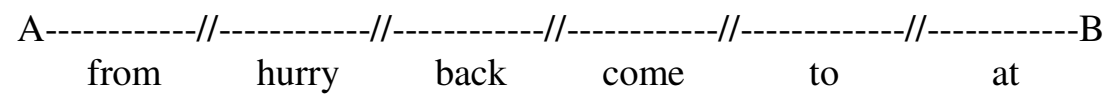

Figure 3: Fully decomposed actions of the event described in sentences $(5 a-5 d)$ 
Table 4: Comparison of foregrounded features of the sentence 'John hurried back to the hospital from his office' in English, Thai and Chinese

\begin{tabular}{|l|c|c|c|c|}
\hline \hline Action verbs & ENG (a) & TH(b) & CHN (c) & CHN(d) \\
\hline from & from & t6à:k & cóng & cóng \\
hurry & hurry & rî:p & găn & găn \\
back & back & klàp & huí & huí \\
come & $\varnothing$ & ma: & lái & $\emptyset$ \\
to & to & $\varnothing$ & dào & dào \\
at & $\varnothing$ & $\mathrm{t}^{\mathrm{h}} \hat{\mathrm{i}}$ : & $\varnothing$ & $\varnothing$ \\
\hline
\end{tabular}

We can deduce six global features (from, hurry, back, come, to, at) from the sentences of the three regional languages above. However, each individual language may select different features. English and Chinese are similar in that they choose the actions indicating the initial point and the projected goal (from...to). Thai also expresses the starting point of the action, but it only employs at, which suggests that the action takes place in a specific location.

If we scrutinize the word order of these three regional languages in Example (5), we can find that the position of the directional locative (from), which expresses the starting point, precedes the reached goal (to) in Chinese and Thai, but this phenomenon is considered to be ungrammatical in the English sentence. In discussing word order in Chinese, Tai (1985) explains that an action that occurs first will normally be placed in the front.
One of the examples he raises is in terms of temporal sequence: moving toward a location precedes arriving at the location, while arriving at the location follows moving toward the location. Thus, in Chinese and Thai, 'from' is expressed before 'to'.

From the above examples, we can see the decomposition process at the sentence level. In fact, decomposition can also be found at the lexical level. The data in the table below show that Thai and Chinese employ the locative particle loy/xià 'descend' in such a way. We can use the Global Grammar theory to explain this phenomenon in most cases. Thai and Chinese choose a more decomposing way of expressing the idea of moving actions from the upper level to the lower level by using either $\mathrm{V}+\mathrm{N}$ or $\mathrm{V}+\mathrm{V}$. In English, the actions are compressed into specific verbs, as illustrated in Table 5. 
Table 5: The action verb 'descend' in Chinese and its Thai and English equivalents

\begin{tabular}{|c|c|c|c|}
\hline Action verbs & ENG & $\overline{\mathrm{TH}}$ & $\mathrm{CHN}$ \\
\hline (1) to fish & to fish & loy bèd $(\mathrm{V}+\mathrm{N})$ & chuí diào $(\mathrm{V}+\mathrm{V})$ \\
\hline (2) to debark & to debark & loy tøà:k ru:a $(\mathrm{V}+\mathrm{V}+\mathrm{N})^{9}$ & xià chuán $(\mathrm{V}+\mathrm{N})$ \\
\hline (3) to bury & to bury & loy făn $(\mathrm{V}+\mathrm{V})$ & xià zàng (V+V) \\
\hline (4) to dismount & to dismount & loy t6à:k má: $(\mathrm{V}+\mathrm{V}+\mathrm{N})$ & xià mă $(\mathrm{V}+\mathrm{N})$ \\
\hline (5) to sign & to sign & $\log \mathrm{t} 6^{\mathrm{h}} \mathrm{u}:(\mathrm{V}+\mathrm{N})$ & qiānmíng $(\mathrm{V}+\mathrm{N})$ \\
\hline (6) to register & to register & $\operatorname{lo\eta } \mathrm{t}^{\mathrm{h}}$ ábi:an $(\mathrm{V}+\mathrm{N})$ & dēngjì $(\mathrm{V}+\mathrm{V})$ \\
\hline
\end{tabular}

Note: $\mathrm{N}$ stands for noun; $\mathrm{V}$ stands for verb.

\footnotetext{
${ }^{9}$ It is quite interesting that in Thai we can use the term log rul:a (descend-boat) or $k^{h} u \hat{n}$ rul: $a$ (ascend-boat) to express the meaning 'get onto the boat.' Patcharatee (1990) gives a clear explanation that log in log rul:a expresses the motion towards the destination. In the past, Thai people used the term log rul:a instead of $k^{h}$ un $r$ ll: $a$ to express the meaning of 'get onto the boat' because the position of a port in the old days was higher than the boat itself and the people had to step down the stairway of the port before they got onto the boat. The opposite term of loy rul:a is $k^{h} u \hat{n}$ t6à: $k$ rul: a (ascend-from-boat) 'get off the boat'. However, at present, when we go to see a big boat exhibition which displays a boat in a place higher than the ground, we can also use the term $k^{h}$ un $r u l: a$ (ascend-boat) instead of log rul:a (descend-boat) to express the meaning of 'getting on the boat'. The term lon tøà: $k$ rul:a (descend-from-boat) 'get off the boat' applies to the opposite situation.
} 
Take (3) in the Table 5 for example, loy $f \breve{a} y$ in Thai and xià zàng in Chinese are decomposed expressions which correspond to the compression 'bury' in English, as shown in Figure 4.

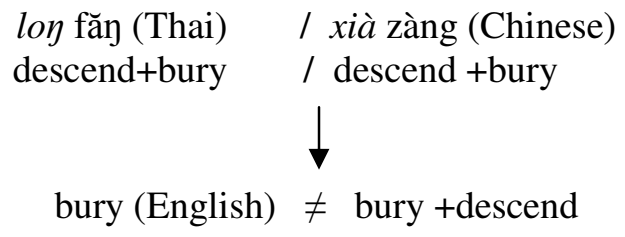

Figure 4: Action verb 'bury' in Table 5 and its Thai and Chinese equivalents

One may wonder why the action verb down is not foregrounded in English. In fact, the action verb down is a hidden feature in the English action verb bury, which expresses the action of moving from an upward to a downward position. It is, therefore, no surprise that English only foregrounds the action verb bury.

\section{Analysis of directional complements 'come' and 'go'}

As discussed earlier, Thai and Chinese tend to express an event in a more decomposing manner than English does. One particular case of decomposition in Thai and Chinese concerns the directional complements ma:/lái 'come' and paj/qù 'go.' These two directional complements not only express the actions of 'coming' and 'going' but also indicate the directions of motion towards and away from the speaker. However, these two directional complements are backgrounded in English. Consider the following set of examples:

(6) a. Zhangsan entered (toward the speaker).

(English)

b. T6a:nsa:n $d \gamma: n k^{h} \hat{a} w$ ma: lغ́:w Zhangsan walk enter come Perf. 'Zhangsan entered (toward the speaker)'

c. T6a:ysa:n $k^{h} \hat{a} w$ ma: lर́:w Zhangsan enter come Perf.

'Zhangsan entered (toward the speaker)' 


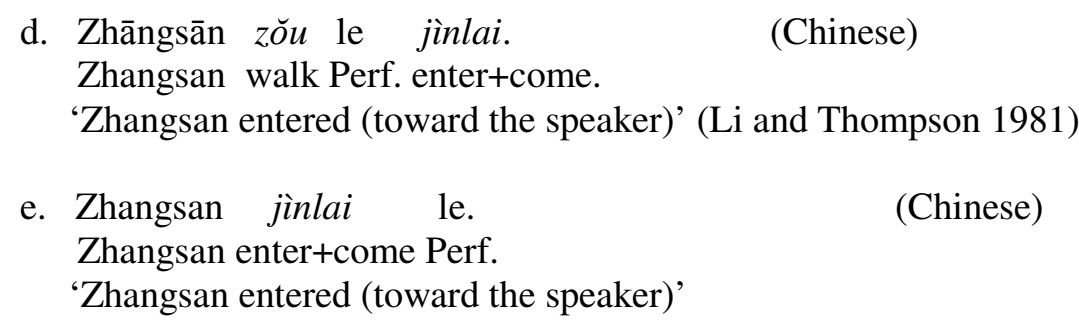

We can see from (6b) and (6e) that in Thai and Chinese the presence of ma:llái is important since it indicates the action 'come toward the speaker' and thus allows us to know that Zhangsan, who was entering, was in the sight of the speaker. Similarly, the presence of paj/qù in (7b) and (7e) entails that Lisi, who was

a. Lisi entered (away from the speaker).

b. Lisi $d \gamma: n k^{h} \hat{a} w$ paj lé:w Lisi walk enter go Perf.

'Lisi entered (away from the speaker)'

c. Lisi $k^{h} \hat{a} w$ paj lé:w

Lisi enter go Perf.

'Lisi entered (away from the speaker)'

d. Ľsì zŏu jìnqu le.

Lisi walk enter+go Perf.

'Lisi entered (away from the speaker)'

e. Lisì jìnqu le.

Lisi enter+go Perf.

'Lisi entered (away from the speaker)' entering, was going away from, and was outside the sight of the speaker. That is why both ma:/lái 'come toward the speaker' and paj/qù 'go away from the speaker' should be foregrounded in Thai and Chinese.
(English)

(Thai)

(Thai)

(Chinese)

(Chinese) 
Consider one more example:

(8) a. John fell off the roof (toward the speaker)

(English)

b. T6ว:n tòk $l o \eta^{10} \quad m a:$ tøà:k lăyk $\mathrm{k}^{\mathrm{h}} \mathrm{a}$ :

(Thai)

John fall descend come from roof

'John fell off the roof'

c. Yuēhàn cóng wūdǐngshang diào le xiàlai.

(Chinese)

John from on the roof fall Perf. descend+come

'John fell off the roof'

In example (8) all the sentences describe the event 'John fell off the roof.'

\footnotetext{
${ }^{10}$ In Thai, the action verb log 'descend' can be backgrounded when it occurs after the action verb tòk 'fall'. Thus, to describe the event John fell off the roof, we can also use Tढ̆:n tòk tøà.k lăjk $\mathrm{k}^{\mathrm{h}}$ a: 'Johnfell-from-roof'. In standard Chinese, though we can compress the four actions in (8c) into two actions: Yuēhàn diào xià wūdǐng 'John-fell-descend-roof', xià 'descend' is still the significant feature and cannot be dropped.
} 
Thai and standard Chinese exhibit the sequence of action verbs and directional complement ma:/lái "come toward the speaker', while this feature is not mentioned or backgrounded in English.

\section{Pecagogical implications}

Before we delineate how to use the Global Grammar framework to help L2 learners understand the second language, it is necessary to give a brief review of how the Grammar-Translation method deals with L2 teaching since the GrammarTranslation method is the most traditional approach of second language teaching and is still popular in some parts of the world today.

According to Brown (1994), the primary language of instruction is the first language (L1) in the Grammar-Translation method. Syntactic properties or formal aspects of the second language (L2) are explained elaborately in L1, and vocabulary lists accompanied with L1 translation equivalents are memorized. However, as Yule (1996) points out, this method does not work well for actual use of L2 because this method benefits L2 learners mostly in the written rather than the spoken language. Also, Omaggio (1993) comments that the expectation of right answers and 'correct' grammar in this method, as well as the scant regard for actual use and oral production, can be intrinsic drawbacks to this approach. To illustrate, let us refer back to the sentence Mălì zuò féijì dào Béijing qù 'Mary takes a plane to Beijing' in example (2) and see how a foreign language teacher uses the Grammar-Translation method to teach Chinese to a class of American or Thai learners. The teacher may use an L1 translation equivalent sentence in English or Thai to explain the meaning of the L2 sentence or ask the students to translate the L2 sentence into its L1 counterpart. Since the Grammar-Translation method emphasizes syntactic accuracy, or the form, rather than fluent communication of meaning in L2, L2 learners may memorize L1 sentences and L2 translation equivalents without conceptualizing the specific differences and interrelationships between L1 and L2 in syntactic structures and semantic features. In the case of the example here, American students may not be able to understand why Chinese uses the action verbs zuò 'sit' to describe the action 'takes an airplane.' Similarly, Thai students may not be able to see why Thai uses both the action verbs nây 'sit' and $k^{h} u \hat{n}$ 'get on' to express the action of 'takes a plane to Beijing'. Presumably, these problems can be avoided in a classroom where the principles of the Global Grammar approach are adopted. By giving L2 learners explicit analysis and instruction of global features from regional languages, we can expect the learners to develop an awareness and deeper understanding of the interrelationships and interactions of syntactic structures and semantic features in L1 and L2. However, empirical evidence is needed for such a hypothesis to be confirmed.

In addition, Global Grammar may possess a unique advantage in dealing with L2 instruction of L2 learners with multilingual backgrounds. Ellis (2005) argues that taking into account individual differences in L2 learners is a basic principle of successful L2 instruction. However, this principle is not easy to implement, especially if L2 instruction involves learners with different L1 backgrounds. This is because L2 learners with multilingual backgrounds often have different needs and it is often beyond a 
teacher's ability to explain the L2 in several different languages. Global Grammar may be a solution to this practical problem. According to Hsieh (2004, 2005), an increasing number of languages that are compared in the Global Grammar approach can result in a possible ultimate range of the features in the global expression. Once Global Grammar creates the maximal range of the standard global expression, it will be able to deal with all the regional expressions. For a multilingual classroom setting, teachers may make use of global features to explain the L2 to L2 learners and help them to analyze the L2 in their own L1 regional expressions no matter how different their L1 backgrounds are. Let us take the Chinese sentence Mălì zuò féij̄̄ dào Béijing qù 'Mary takes a plane to Beijing' in (2) as an example. With the help of Global Grammar, American and Thai learners can construct a full image of all the decomposed actions in this event in both their L1 and L2, which may make it easier for them to perceive the principles governing the operations and interactions of semantic and syntactic features in Chinese. Thus, Thai and American learners may better perceive the event Mălì zuò féijì dào Béijīng qù 'Mary takes a plane to Beijing' in light of the decomposition in the global expression and their regional expressions, as indicated in Figure (6) and Table (5).

$$
\begin{aligned}
& \text { A-----initial action-----//-----middle action-----//-----final action-----B } \\
& \text { get on the plane sit on the plane reach the destination }
\end{aligned}
$$

Figure 6: Decomposition of the event 'Mălì zuò fêijī dào Béijīng qù'

Table 5: Comparison of foregrounded features of the sentence 'Mary takes a plane to Beijing' in English, Thai and Chinese

\begin{tabular}{|l|c|c|c|c|c|}
\hline $\begin{array}{l}\text { Action } \\
\text { verbs }\end{array}$ & ENG (a) & TH (b) & TH (c) & CHN (d) & CHN(e) \\
\hline take & take & $\varnothing$ & $\mathrm{k}^{\mathrm{h}}$ ûn & $\varnothing$ & $\emptyset$ \\
sit & $\varnothing$ & nây & $\varnothing$ & zuò & zuò \\
to & to & $\varnothing$ & $\varnothing$ & $\varnothing$ & dào \\
go & $\varnothing$ & paj & paj & qù & qù \\
\hline
\end{tabular}

In this way, American learners can learn that the feature zuò 'sit' is emphasized or foregrounded in Chinese, which explains why Chinese uses the action verb zuò 'sit' to describe the action 'takes an airplane.' In a similar way, Thai learners can understand that Thai shares features in the two regional expressions for describing the event with both Chinese and English, which accounts for why Thai uses both the action verbs $n \hat{a} \eta$ 'sit' and $k^{h} u \hat{n}$ 'get on' to express the action of 'takes a plane to Beijing.' 


\section{Conclusion}

This paper offered an overview of the basic principles entailed in the Global Grammar theory and potential pedagogical implications of this theory, and demonstrated how Global Grammar operates by describing the temporal sequences of an event and two processes of language expression (i.e., compression and decomposition). The analysis of the two unique directional complements in Thai and Chinese come and go showed how compression and decomposition processes help to reveal subtle differences in syntax and semantics across different languages. The paper also argued that Global Grammar can help L2 learners in understanding and learning L2, especially when L2 learning takes place in multilingual classroom settings.

For L2 learners, Global Grammar can help them to learn their L2 in a more analytical manner. Through comparing similarities and differences between languages, learners can infer global features from regional expressions. Moreover, learning how to decompose actions in an event through a comparison of regional languages will help L2 learners to understand temporal sequences and foregrounding and backgrounding of global features. For teachers, Global Grammar has revealed promising potential in its applicability to L2 teaching in that teachers can make use of global features to make L2 easier to understand. Global Grammar can also help teachers to explain complicated interrelationships of syntactic and semantic features in L2 in a more systematic way. Although Global Grammar needs more data from different languages to corroborate its major claims, it has made important theoretical contributions to both linguistic studies and L2 acquisition research.

\section{References}

Brown, H. 1994. Teaching by principles: An interactive approach to language pedagogy. Englewood Cliffs, New Jersey: Prentice Hall Regents.

Chang, Y. 1998. Beyond constituent structures: Semantic structure representations. Proceedings of the Ninth North American Conference on Chinese Linguistics 1: 35-46, University of Southern California.

Ellis, R. 2005. Principles of instructed language learning. Asian EFL Journal 7: 9-24.

Hayden, J. 1997. Fang shu, fang pi, fang fengzheng: A gestalt and its images. Paper presented at the Ninth North American Conference on Chinese Linguistics. Victoria, Canada: University of Victoria.

Hsieh, H. I. 1992. Lexicon and morphology in a compositional cognitive grammar. Proceedings of Is CLL-3. Hsinchu: Tsing Hua University, pp. 38-61.

---. 1994. A computational syntax and its application to parsing. Proceedings of the Seventh R. O.C. Computational Linguistics Conference(ROCLING VII). Hsinchu: Tsinghua University, pp. 243-52.

---. 2000. The subject chain in a compositional cognitive grammar. Language and Linguistics 1.1: 61-88. 
---. 2004. Toward a global cognitive grammar. Proceedings of the Ninth International Symposium on Chinese Languages and Linguistics, $e d$. By Shuanfan Huang. Taipei: National Taiwan University, pp.173191.

---. 2005. Toward a global grammar of Chinese. POLA forever: Festschrift in honor of Professor William S-Y. Wang on his 70th birthday, ed. by Dah-an Ho and Ovid J.L. Tzeng. Taipei: Institute of Linguistics, Academia Sinica, pp.1-17.

---. 2006. The three types of semantic opacity and their challenge of teachers of Chinese. Journal of Chinese Language Teaching 3. 1: 83-116.

Li, N.C \& Thompson, S.A. 1981. Mandarin Chinese: A functional reference grammar. Berkeley: University of California Press.

Omaggio, A. 1993. Teaching language in context ( 2 nd ed.). Boston, MA: Heinle and Heinle.

Patcharatee, S. 1990. On the semantics of the Thai verbs of downward motion (กริยาแสดง ทิศทางลงในภาษาไทย ลง/ตก). Language and Linguistics (ภาษาและ ภาษาศาสตร์) 8. 2: 19-29.

Tai, James H-Y. 1985. Temporal sequence and Chinese word order. Southern Illinois University at Carbondale.
Wang, H. 1998. Prototype, exemplars, and images. Proceedings of the Ninth North American Conference on Chinese Linguistics 2: 251-267, University of Southern California.

Yule, G. 1996. The study of language. Cambridge: Cambridge University Press. 